IZA DP No. 9382

Do Gays Shy Away from Competition?

Do Lesbians Compete Too Much?

Thomas Buser

Lydia Geijtenbeek

Erik Plug

September 2015

Forschungsinstitut

zur Zukunft der Arbeit

Institute for the Study

of Labor 


\title{
Do Gays Shy Away from Competition? Do Lesbians Compete Too Much?
}

\author{
Thomas Buser \\ University of Amsterdam
}

Lydia Geijtenbeek

University of Amsterdam

Erik Plug

University of Amsterdam

and IZA

\section{Discussion Paper No. 9382 \\ September 2015}

\author{
IZA \\ P.O. Box 7240 \\ 53072 Bonn \\ Germany \\ Phone: +49-228-3894-0 \\ Fax: +49-228-3894-180 \\ E-mail: iza@iza.org
}

Any opinions expressed here are those of the author(s) and not those of IZA. Research published in this series may include views on policy, but the institute itself takes no institutional policy positions. The IZA research network is committed to the IZA Guiding Principles of Research Integrity.

The Institute for the Study of Labor (IZA) in Bonn is a local and virtual international research center and a place of communication between science, politics and business. IZA is an independent nonprofit organization supported by Deutsche Post Foundation. The center is associated with the University of Bonn and offers a stimulating research environment through its international network, workshops and conferences, data service, project support, research visits and doctoral program. IZA engages in (i) original and internationally competitive research in all fields of labor economics, (ii) development of policy concepts, and (iii) dissemination of research results and concepts to the interested public.

IZA Discussion Papers often represent preliminary work and are circulated to encourage discussion. Citation of such a paper should account for its provisional character. A revised version may be available directly from the author. 
IZA Discussion Paper No. 9382

September 2015

\title{
ABSTRACT
}

\section{Do Gays Shy Away from Competition? Do Lesbians Compete Too Much?*}

It is an established fact that gay men earn less than other men and lesbian women earn more than other women. In this paper we study whether differences in competitive preferences, which have emerged as a likely determinant of labour market differences between men and women, can provide a plausible explanation. We conduct an experiment on a Dutch online survey panel to measure the competitiveness of gay, lesbian and straight panel members. For differences in competitiveness to partially explain sexual orientation differences in earnings, gay men would need to be less competitive than other men and lesbian women more competitive than other women. Our findings confirm this competitiveness hypothesis for men, but not for women. Gay men compete less than other men, while lesbian women compete as much as other women. Linking our experimental measure to survey data, we show that competitiveness is a significant predictor of earnings. Differences in competitiveness can account for a significant portion of the gay earnings penalty, but cannot explain the lesbian premium.

JEL Classification: $\quad \mathrm{C} 90, \mathrm{~J} 15, \mathrm{~J} 16, \mathrm{~J} 24, \mathrm{~J} 31$

Keywords: experiments, sexual orientation, gender, competitiveness, education, earnings

Corresponding author:

\author{
Erik Plug \\ Department of Economics \\ University of Amsterdam \\ Roetersstraat 11 \\ 1018 WB Amsterdam \\ The Netherlands \\ E-mail: e.j.s.plug@uva.nl
}

\footnotetext{
* We thank seminar and conference participants in Amsterdam, Izmir and Maastricht for their comments and suggestions. Data in this article are, in part, taken from the Longitudinal Internet Studies for the Social Sciences (LISS). The LISS panel data are collected by CentERdata (Tilburg University, The Netherlands) through its MESS project funded by the Netherlands Organization for Scientific Research.
} 


\section{Introduction}

In this paper we investigate sexual orientation differences in taste for competition. In particular, we introduce a short version of the seminal competition experiment of Niederle and Vesterlund (2007) to measure the competitiveness of gay, lesbian and straight panel members in a representative Dutch online survey. ${ }^{1}$ We then match this experimental competitiveness measure with realized labour market outcomes and investigate whether sexual orientation differences in competitiveness can explain sexual orientation differences in earnings.

Sexual orientation differences in earnings are well documented but not well understood. While most empirical studies find that gay men earn less than straight men and lesbian women earn more than straight women (see Klawitter, 2015 for a recent meta-analysis on the topic), it has proven difficult to distinguish between the typical explanations for differences in earnings, including differences in productivity, differences in tastes, and a discriminating labour market. In the case of taste for competition, however, we have a better chance of doing so. If taste for competition drives the typical income differences for gays and lesbians, we should find that in a competition experiment gays are less competitive than straight men and lesbians are more competitive than straight women.

Our study is also of broader interest. Gender differences in willingness to compete are well established inside the laboratory and widely believed to have important effects outside the laboratory. While many experimental studies show that women shy away from competition and men compete too much (Niederle and Vesterlund, 2007, 2011), only few empirical studies have successfully linked gender differences in willingness to compete to gender differences in education or labour markets (Buser, Niederle, and Oosterbeek, 2014; Flory, Leibbrandt, and List, forthcoming; Zhang, 2012; Reuben, Wiswall, and Zafar, 2013; Berge et al., forthcoming). If important economic decisions - including educational and occupational choices - are indeed influenced by someone's willingness to compete, we should find that differences in willingness to compete predict differences in earnings for different groups of workers.

The main results of our competition experiment indicate that gays compete less than straight men, whereas lesbians compete at similar levels as straight

\footnotetext{
${ }^{1}$ Throughout the paper, we use gays in reference to homosexual men and lesbians in reference to homosexual women.
} 
women. When we link our experimental measure of competitiveness to real world outcomes, we find that competitiveness has a positive, sizable and statistically significant influence on earnings. Thus, differences in competitiveness can account for a significant portion of the gay gap, but cannot explain the lesbian premium. Additionally, we find that gender differences in competitiveness, which are comparable to those found in most other experimental studies, are significantly related to the gender gap in earnings.

The remainder of the paper proceeds as follows. Section II discusses possible explanations for sexual orientation differences in earnings. Section III introduces the online experiment. Section IV briefly describes the experimental and survey data. Section $V$ reports the main results on sexual orientation differences in competitiveness and their implications for sexual orientation differences in labour market earnings. Section VI highlights the implications and conclusions of this study.

\section{Background}

In this section, we briefly discuss why sexual orientation may affect earnings in the observed way; that is, gay men earn less than straight men, whereas lesbian women earn more than straight women. We follow a standard framework outlined in most economic studies on earnings differentials and distinguish three potential origins of differences in pay: differences in treatment (in particular labour market discrimination), differences in skills, and differences in preferences.

\section{Labour market discrimination}

Perhaps the most studied explanation for sexual orientation differences in earnings is labour market discrimination. We speak of labour market discrimination when firms (including their employers, employees and clients) treat gays and lesbians differently than straight men and women with similar productive skills. Economists distinguish two models of discrimination. In taste-based discrimination models (Becker, 1971), firms dislike gays and lesbians. In information-based discrimination models (Arrow, 1973; Phelps, 1972), firms use observable characteristics of gays and lesbians to assess their unobservable productivity skills. Both models have the potential to explain part of the sexual orientation differences in earnings. One the one hand, gay workers 
may earn less than straight male workers if firms hold more hostile attitudes against gays than against lesbians. On the other hand, lesbian workers may earn more than straight female workers if firms believe that the stereotypical lesbian worker is more career driven, is less likely to have children, or has more masculine skills.

With conventional labour market surveys and registers, it is difficult to cleanly demonstrate whether gays and lesbians earn differently because of discrimination (taste-based or information-based). There are, however, alternative empirical approaches. One approach, which takes a taste-based discrimination perspective, relies on subjective attitude questions to measure the discriminatory intentions of employers and employees directly. Some studies in social psychology, for example, compare self-reported measures of homophobic attitudes and find that discriminatory tastes are much more pervasive against gays than against lesbians (Herek, 2000; Kite and Whitley, 1996). Some studies in economics link homophobic attitudes to labour market behavior. Black et al. (2002) show that gay and lesbian couples in the US are more likely to live in richer and more tolerant cities. Hammarstedt, Ahmed, and Andersson (2015) show that Swedish gays, but not lesbians, earn more in more gay and lesbian friendly neighborhoods. And Plug, Webbink, and Martin (2014) show that gays and lesbians sort into more gay and lesbian tolerant occupations using a sample of Australian twins.

Another approach relies on field experiments to measure the extent of labour market discrimination. In these experiments, fake resumes with manipulated indications of sexual orientation (while holding all other resume characteristics constant) are sent to firms that advertised jobs. Firms are said to discriminate if fake applicants who appear gay or lesbian are less likely to receive a callback. Examples of these so-called correspondence test studies are Weichselbauer (2003, 2015), who finds that lesbians receive fewer callbacks than straight women in Vienna and Munich, but not in Berlin; Tilcsik (2011), who observes lower callback rates for gays among male applicants in the US, with the lowest callback rates in those states that are perceived as gay unfriendly; Drydakis (2009, 2011), who finds severe discrimination against gays and lesbians in Greece; and Ahmed, Andersson, and Hammarstedt (2013), who find that gays and lesbians are treated unfavourably in Sweden, with the lowest callback rates in male-dominated occupations for gays and female-dominated occupations for lesbians. 
To what extent are the earnings differences between gay, lesbian and straight workers driven by discrimination? The evidence is mixed. While it is theoretically possible to predict the observed wages of both gays and lesbians within a discriminating labour market, the empirical evidence on discrimination appears most consistent with the observed wages of gays, and not of lesbians.

\section{Differences in skills}

Another traditional explanation for differences in earnings is differences in productive skills. Economists often emphasize that workers obtain their productive skills through schooling and work experience. In human capital models (Becker 1964; Mincer 1974), for example, expectations about labour market earnings drive the relationship between sexual orientation and educational attainment. If gay and lesbian students take the gay penalty and lesbian premium into account, human capital models would predict that gays will spend fewer years in school than other men, whereas lesbians will spend more years in school than other women. The empirical evidence again appears mixed. While most empirical studies, listed in the meta-analysis of Klawitter (2015), indeed report that lesbians are better educated than other women, the common finding that gays are better educated than other men runs counter to what human capital models predict. ${ }^{2}$

In alternative models of household specialization (Becker, 1981), expectations about having children (or the absence thereof) can lead to differences in work experience between gay, lesbian and other workers. If gay and lesbian couples are less likely to have children and thus less likely gain from specialization, models of household specialization predict that gays work less and as a consequence accumulate fewer productive skills than other men, and reversely that lesbians work more and accumulate more productive skills than other women. While these explanations certainly capture part of the actual earnings patterns (Black et al., 2003; Black, Sanders, and Taylor, 2007), formal evidence is scarce. Some studies investigate the division of labour in gay, les-

\footnotetext{
${ }^{2}$ There are other reasons why gays and lesbians may, on average, appear better educated. Gays and lesbians have the option to hide their true sexual orientation in surveys. If gays and lesbians raised in more tolerant and better educated families are more likely to reveal their sexual orientation, we expect to find that gays and lesbians are, on average, better educated. With this in mind, we would then expect no such schooling differences within families. This is not the case. In Plug, Webbink, and Martin (2014), a comparison of educational attainment within identical twin pairs shows that gays and lesbians are better educated than their straight twin siblings.
} 
bian and straight couples. In general, these studies find that gay men work less than other men, whereas lesbian women work more than other women. Additional evidence is then taken from earnings regression models, in which several specialization-related covariates are added, including the presence of children, work experience and its square, part-time work (and variations thereof). After including these covariates, the same studies continue to find penalties for gays and premia for lesbians that are sizable and statistically significant (Antecol, Jong, and Steinberger, 2008; Baumle and Poston, 2011; Tebaldi and Elmslie, 2006).

Do sexual orientation differences in earnings arise from sexual orientation differences in productive skills? The existing theories of human capital and household specialization are successful in capturing some elements of the sexual orientation differences in earnings, but certainly not all.

\section{Differences in tastes}

If preferences systematically differ by sexual orientation, this could partially explain the observed differences in labour market outcomes. Empirical research on the role of preferences for labour market differences between heterosexuals and homosexuals is scarce and we therefore draw upon the large empirical literature in behavioral economics on gender differences in preferences, to understand which particular preferences may matter for earnings, and in what way.

Possible preference-related explanations for sexual orientation differences in labour market outcomes include, among others, differences in competitiveness, differences in risk preferences, differences in social preferences, and differences in willingness to negotiate. See Bertrand (2011) for a survey on gender differences in such preferences as a possible explanation for gender differences in labour market outcomes. Of these gender differences in preferences, the gender gap in competitiveness is the one which is most consistently found in the lab and largest in magnitude. If we take the gay penalty and lesbian premium at face value, it is quite clear how the sexual orientation differences in competitive preferences should look like. If competitive workers are more likely to sort into more competitive and higher paid professions, we expect gays to be less competitive than straight men and lesbians to be more competitive than straight women. ${ }^{3}$ But what do we actually know about the sexual orientation

\footnotetext{
${ }^{3}$ Similarly, if risk averse workers are more likely to sort into lower paid but more stable
} 
differences in such preferences? Not much. There is, to this date, no empirical research that looks at sexual orientation differences in competitiveness or any other economic preferences.

To wrap up, we have considered three standard explanations for sexual orientation differences in earnings, including differences in productivity, differences in tastes, and a discriminating labour market. Empirical evidence in favour of productivity differentials and discrimination is far from overwhelming. Empirical evidence in favour of (or against) differentials in economic preferences is essentially nonexistent. In this paper, we aim to fill this gap by focusing on competitiveness, one of the most promising preference factors to emerge from the behavioral economics literature on gender differences. In particular, we investigate whether willingness to compete differs between gay and straight men and lesbian and straight women and whether such differences can explain the observed earnings of men and women, and gays and lesbians in particular.

\section{$3 \quad$ Sampling and experimental design}

We conduct our competitiveness experiment on the LISS panel, a representative Dutch online panel of 5000 households whose members respond to monthly questionnaires. ${ }^{4}$ Academic researchers can apply to add questionnaire items or conduct simple experiments. The main advantage of using the LISS panel is the large amount of data already available on the panel members. This allows us to select gay and lesbian participants without informing them that we are interested in their sexual preferences, thus avoiding priming. Furthermore, it allows us to link our experimental results to survey data on income and educational careers.

professions, we would expect gays to be more risk averse than straight men and lesbians to be less risk averse than straight women. If workers' altruism interferes with their financial success, we would expect that gays are more socially minded than straight men and lesbian are less socially minded than straight women. And if salaries are partially driven by willingness to negotiate, we would expect gays to be less keen to negotiate their salaries and lesbians to be more willing to do so. Bertrand (2011) also discusses differences in gender identity. In case of social norms tied to sexual identities, we can use the identity model of Akerlof and Kranton (2000) to predict the earnings penalty of gays, but not the earnings premium of lesbians. The argument is as follows. If workers derive utility from the wages they earn as well as the identity they most relate to, both gays and lesbians who disclose their sexual identity at work are willing to forgo some earnings in exchange for identity utility.

${ }^{4}$ Data and documentation from the LISS panel are available at http://www.lissdata.nl/. 
Table 1: Sample

\begin{tabular}{llcccc}
\hline & & LISS population & Sample & \multicolumn{2}{c}{ Participation } \\
\hline & all & active & active & active, $<65$ \\
& & $(1)$ & $(2)$ & $(3)$ & $(4)$ \\
\hline Male & straight & 4,146 & 157 & 124 & 80 \\
& gay & 163 & 77 & 66 & 46 \\
\multirow{2}{*}{ Female } & straight & 4,795 & 172 & 134 & 112 \\
& lesbian & 164 & 84 & 61 & 47 \\
\hline Total & & 9,268 & 490 & 385 & 296
\end{tabular}

Note: column 1 counts all panel members with information on sexual preferences. Columns 2-4 includes only members who were still actively participating in November 2013 and were thus able to participate in the experiment.

The questionnaires contain a couple of items that help us to identify lesbian and gay panel members. A 2009 questionnaire asked "Are you attracted to men or to women?", with answers on a five-point scale: 1 only to men; 2 especially to men, but to some extent also to women; 3 as much to men as to women; 4 especially to women, but to some extent also to men; 5 only to women. Our gay sample includes men who answered 1,2 or 3 and our lesbian sample includes women who answered 5, 4 or $3 .^{5}$ This question was answered by 4,794 panel members. We further use the question "What is your partner's gender?" which was asked yearly from 2008 to 2012. Panel members who at least once stated having a partner of the same sex are added to the gay and lesbian samples whereas those who always stated to be single or with a partner of the other gender are added to the heterosexual sample. We omit individuals for whom the answers to the sexuality question and the partner question conflict. This gives us 9,268 individuals, 163 of whom are gay and 164 of whom are lesbian. Of these, 5,357 individuals are still active panel members at the time of the experiment (see Table 1). An active panel member is defined here as a member who has participated in at least one survey round within the last 3 months.

To obtain a measure of competitiveness, we conducted an incentivised online experiment. We invited all active homosexual panel members to participate, supplemented by a random selection of heterosexual members, stratified by age and gender. Of these 490 candidates, 385 participated in the experiment, 66 of whom are gay and 61 of whom are lesbian. In the main empirical analysis, however, we work with the subsample of working-age individuals

\footnotetext{
${ }^{5}$ The gay and lesbian samples therefore also include bisexual individuals.
} 
Figure 1: Matrix task
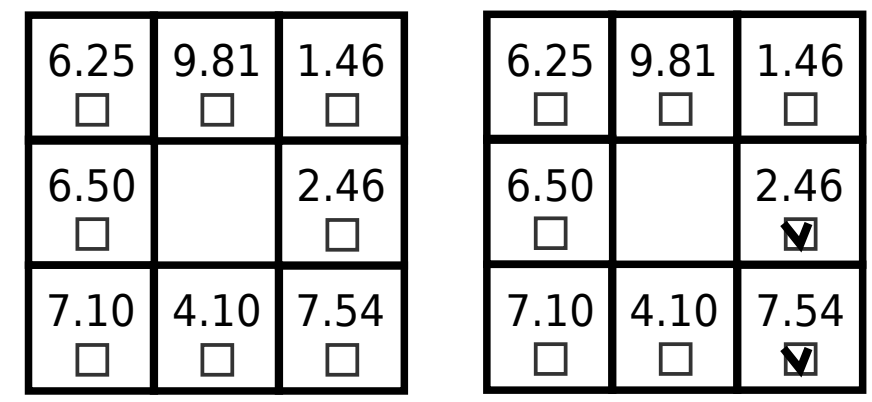

(see Table 1). The experimental design is similar to the design introduced by Niederle and Vesterlund (2007) which has become the standard in the literature on gender and competitiveness. Participants are paid for their performance in a simple task whereby they can choose between competitive tournament incentives and a non-competitive piece-rate payment. The task consists of a series of matrices with eight numbers. Out of these eight numbers, participants have to find the two numbers which add up to exactly ten (see Figure 1). As soon as they click the correct pair of numbers, the next matrix appears. After reading the instructions, participants receive a series of three matrices for practice, with an option of receiving three more.

The experiment consists of two incentivised rounds of three minutes each. In round 1, participants are paid a piece-rate of 40 euro cents per solved matrix. Their score in this round serves as a baseline performance measure. In round 2, participants can choose how they would like to be paid. In particular, they can choose between a 40 cent piece-rate and entering a winner-takes-all tournament. If they choose the tournament their performance is compared with the performance of one other randomly chosen participant. If they perform better, they earn 100 cents per solved matrix, otherwise they receive nothing. ${ }^{6}$ The choice of payment scheme serves as our measure of competitiveness, with competitiveness equal to 0 for people who choose the piece rate scheme and 1 for those who choose the relative scheme. The experiment is followed by a brief questionnaire which assesses participants' confidence in their own ability for the task and their willingness to take risk, two factors which have been shown to influence the choice of payment scheme (Niederle and Vesterlund, 2011). We measure confidence through the question "What

\footnotetext{
${ }^{6} \mathrm{In}$ case of a tie, each participant receives 50 cents.
} 
do you think is the probability with which you solved more matrices than a randomly selected opponent?" (answers on a scale from 0 to 100 percent). We measure willingness to take risks through the question "Tell us to what extent, in general, you are prepared to take risks". The answer is on a scale from 0 ("totally unprepared") to 10 ("fully prepared"). This question is similar to the risk question used by Dohmen et al. (2011) which has been shown to predict both incentivized choices in a lottery task and risk taking across a number of contexts, including holding stocks, being self-employed, participating in sports, and smoking. Before the start of the first round, participants had a chance to practice the task. The data was collected in March 2014. Participants earned 8.82 Euros on average.

\section{Data}

Table 2 describes some of the basic characteristics of our target sample individuals of working age. The data shows the standard pattern from the experimental gender difference literature. While 37 percent of straight men choose the tournament scheme, only 23 percent of straight women do, even though their first-round performance is statistically indistinguishable. Women also rate themselves as significantly less risk-seeking and are significantly less confident about their performance in the task. Gays and lesbians enter the tournament at similar rates as straight women, 24 and 19 percent respectively. Gays do not differ from straight men in their risk aversion and confidence, nor do lesbians differ from straight women along these characteristics.

To directly test whether our experimental measure of competitiveness can explain labour market differences between heterosexual and homosexual individuals, we use data on income and education levels contained in the LISS data. Income and education are part of the background data questions which are asked every time an individual answers a questionnaire. Our income variable is the average net income over all these observations for each individual. Education is defined in six categories according to the definition of CBS (Statistics Netherlands). We use the most recent observation. The log income of straight women is significantly lower than the log income of straight men. Lesbians earn significantly more on average than straight women whereas there is no significant difference between gay and straight men. 


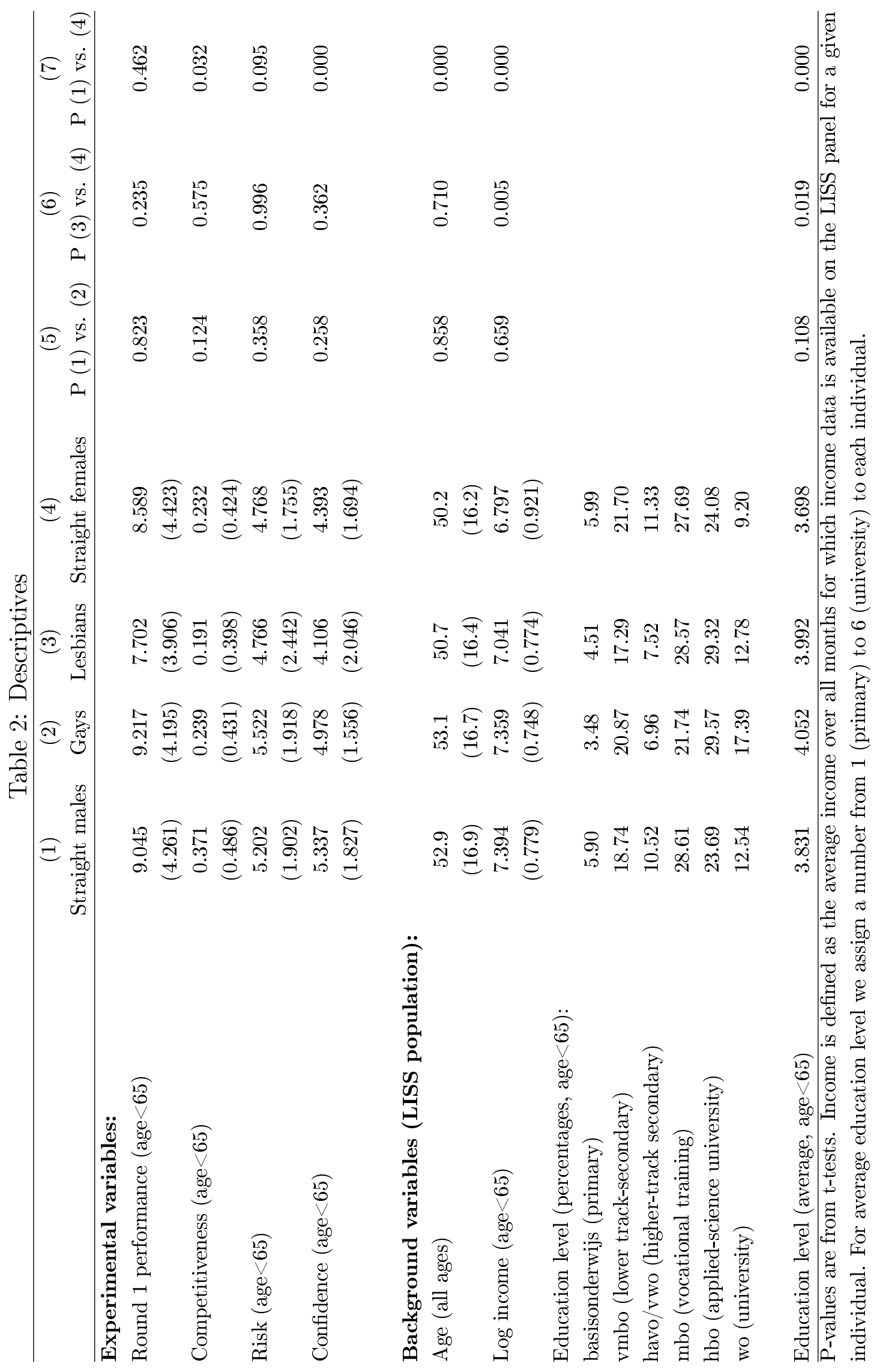




\section{Results}

Table 3 contains the main results. Here we regress a binary variable indicating whether an individual chose the competitive payment scheme on sexual orientation dummies, controlling for first-round scores. We show results for the whole sample as well as the subsample of individuals below 65 years of age, which will serve as the empirical basis for our subsequent analysis on the link between competitiveness and salaries. We find that working-age gays are indeed significantly less competitive than straight men. In the working-age sample, gays are around 14 percentage points less likely to choose the competitive payment scheme conditional on performance. However, there is virtually no difference between the competitiveness of lesbians and straight women. We also replicate the standard finding that straight women are less competitive than straight men, a difference of 12 percentage points for working-age individuals. Controlling for confidence and risk attitudes in column 4 explains about half of the straight gender difference in competitiveness but not the gay effect. These results indicate that individual differences in competitiveness indeed have the potential to explain differences in labour market outcomes between gay and straight men, but not between lesbian and straight women. We should note that when we use the whole sample (and include those older than 65), as we do in columns 1 and 3, the differences in competitiveness get somewhat weaker. This result is comparable to the result reported by Flory et al. (2012). They find that gender differences in competitiveness are weaker in older samples. ${ }^{7}$

To directly test whether individual differences in competitiveness can explain differences in labour market outcomes, we regress log income on sexual orientation dummies and our experimental indicator of competitiveness. The results are presented in Table 4. All regressions control for a quadratic polynomial of age. The results reported in column 1, using the whole LISS sample, confirm the expected income differences: gays earn less than straight men and lesbians earn more than straight women, although this effect is significant only for the lesbians. Controlling for education in column 5 increases the

\footnotetext{
${ }^{7}$ We have also estimated the same regression models on a sample of individuals below 55 and found sexual orientation differences in competitiveness that are more pronounced. In the specification without the risk and confidence covariates, the parameter estimates (with standard errors in parentheses) are -0.194 (0.086), -0.197 (0.086) and -0.157 (0.078) for gays, lesbians and straight females, respectively.
} 
Table 3: Effect of sexual orientation on competitiveness

\begin{tabular}{lcccc}
\hline & $(1)$ & $(2)$ & $(3)$ & $(4)$ \\
& All & $<65$ & All & $<65$ \\
\hline Gay & -0.072 & $-0.138^{*}$ & -0.073 & $-0.144^{* *}$ \\
& $(0.062)$ & $(0.075)$ & $(0.058)$ & $(0.069)$ \\
Lesbian & -0.075 & $-0.130^{*}$ & -0.039 & -0.079 \\
& $(0.064)$ & $(0.076)$ & $(0.063)$ & $(0.072)$ \\
Straight female & $-0.086^{*}$ & $-0.122^{* *}$ & -0.040 & -0.068 \\
& $(0.050)$ & $(0.061)$ & $(0.048)$ & $(0.057)$ \\
Score round 1 & $0.035^{* * *}$ & $0.037^{* * *}$ & $0.022^{* * *}$ & $0.022^{* * *}$ \\
& $(0.005)$ & $(0.005)$ & $(0.005)$ & $(0.006)$ \\
Risk & & & $0.059^{* * *}$ & $0.066^{* * *}$ \\
& & & $(0.010)$ & $(0.012)$ \\
Confidence & & & $0.032^{* *}$ & $0.034^{* *}$ \\
& & & $(0.012)$ & $(0.014)$ \\
\hline Lesbian-Straight f. & 0.011 & -0.008 & 0.001 & -0.011 \\
& $(0.061)$ & $(0.069)$ & $(0.058)$ & $(0.065)$ \\
\hline
\end{tabular}

Coefficients are from OLS regressions with a binary indicator for choosing the competitive remuneration as the dependent variable. In all regressions, the reference group are straight males. Robust standard errors in parentheses; ${ }^{*}, * *$ and ${ }^{* * *}$ denote significance at 10,5 and 1 percent, respectively.

gay income disadvantage, which is now statistically significant, and reduces the lesbian income advantage. Conditional on education, gays earn 12 percent less than straight men and lesbians earn 13 percent more than straight women. We also find a gap of 55 percent between straight men and straight women. ${ }^{8}$ Columns 2 and 6 repeat this exercise using only individuals from the experimental sample for whom we have a measure of their competitiveness. Here, the gay income disadvantage appears somewhat larger.

In columns 3 and 7 , we additionally control for performance in the experiment and in columns 4 and 8 we add competitiveness (i.e. a dummy for choosing the tournament) to the regression. When not controlling for education, competitiveness strongly and significantly predicts income: conditional on performance, those who choose to compete in the experiment earn 17 percent more than those who choose the piece-rate. Controlling for confidence and risk attitudes in column 5 actually increases the bonus for competitive-

\footnotetext{
${ }^{8}$ The reason why this gap is larger than typically reported in the literature is likely due to the high incidence of part-time work among Dutch women (Bosch and Van der Klaauw, 2012).
} 


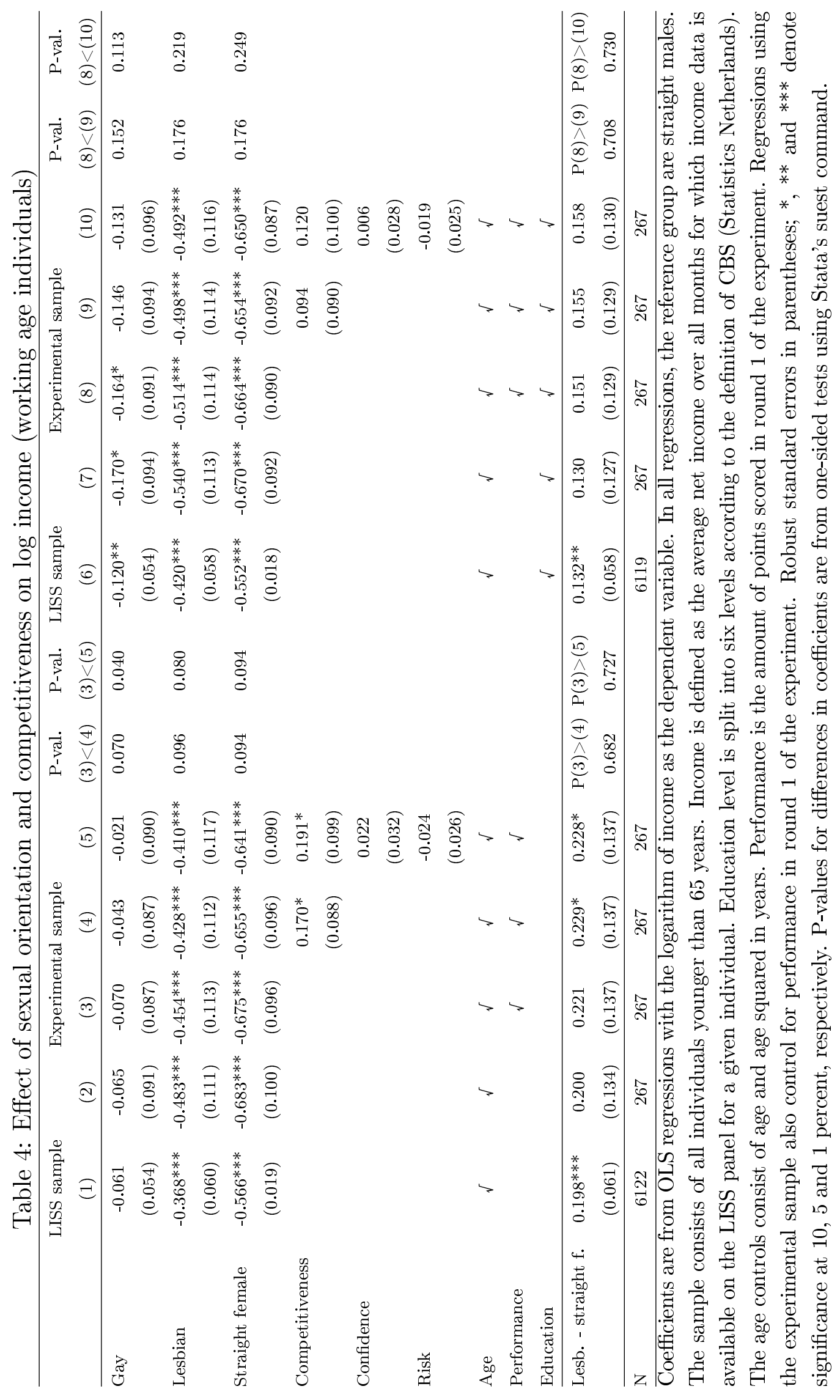


Table 5: Effect of sexual orientation and competitiveness on education level (working age individuals)

\begin{tabular}{|c|c|c|c|c|c|c|c|}
\hline & \multirow{2}{*}{$\begin{array}{c}\text { LISS sample } \\
\text { (1) }\end{array}$} & \multicolumn{4}{|c|}{ Experimental sample } & \multirow{2}{*}{$\begin{array}{l}\text { P-val. } \\
(3)<(4)\end{array}$} & \multirow{2}{*}{$\begin{array}{l}\text { P-val. } \\
(3)<(5)\end{array}$} \\
\hline & & (2) & (3) & (4) & (5) & & \\
\hline \multirow[t]{2}{*}{ Gay } & 0.168 & $0.396^{* *}$ & $0.395^{* *}$ & $0.454^{* *}$ & $0.480^{* *}$ & 0.061 & 0.053 \\
\hline & $(0.106)$ & $(0.198)$ & $(0.199)$ & $(0.197)$ & $(0.199)$ & & \\
\hline \multirow[t]{2}{*}{ Lesbian } & 0.124 & 0.080 & 0.155 & 0.205 & 0.267 & 0.091 & 0.067 \\
\hline & $(0.092)$ & $(0.184)$ & $(0.189)$ & $(0.188)$ & $(0.199)$ & & \\
\hline \multirow[t]{2}{*}{ Straight female } & $-0.101^{* * *}$ & -0.123 & -0.099 & -0.053 & -0.001 & 0.069 & 0.033 \\
\hline & $(0.026)$ & $(0.147)$ & $(0.146)$ & $(0.147)$ & $(0.153)$ & & \\
\hline \multirow[t]{2}{*}{ Competitiveness } & & & & $0.396^{* *}$ & $0.350^{* *}$ & & \\
\hline & & & & $(0.157)$ & $(0.169)$ & & \\
\hline \multirow[t]{2}{*}{ Confidence } & & & & & 0.070 & & \\
\hline & & & & & $(0.044)$ & & \\
\hline \multirow[t]{2}{*}{ Risk } & & & & & -0.009 & & \\
\hline & & & & & $(0.033)$ & & \\
\hline Age & $\sqrt{ }$ & $\sqrt{ }$ & $\sqrt{ }$ & $\sqrt{ }$ & $\sqrt{ }$ & & \\
\hline Performance & & & $\sqrt{ }$ & $\sqrt{ }$ & $\sqrt{ }$ & & \\
\hline \multirow[t]{2}{*}{ Lesbian-Straight f. } & $0.225^{* *}$ & 0.203 & 0.254 & 0.257 & 0.267 & $\mathrm{P}(2)>(3)$ & $P(2)>(4)$ \\
\hline & $(0.092)$ & 0.176 & $(0.181)$ & $(0.182)$ & $(0.184)$ & 0.545 & 0.538 \\
\hline $\mathrm{N}$ & 6985 & 294 & 294 & 294 & 294 & & \\
\hline \multicolumn{8}{|c|}{$\begin{array}{l}\text { Coefficients are from ordered probit regressions with education level as the dependent vari- } \\
\text { able. In all regressions, the reference group are straight males. The sample consists of } \\
\text { all individuals younger than } 65 \text { years. Education level is split into six levels according to } \\
\text { the definition of CBS (Statistics Netherlands). The age controls consist of age and age } \\
\text { squared in years. Performance is the amount of points scored in round } 1 \text { of the experiment. } \\
\text { Regressions using the experimental sample also control for performance in round } 1 \text { of the } \\
\text { experiment. Robust standard errors in parentheses; }{ }^{*}, * \text { and } * * * \text { denote significance at } 10 \text {, } \\
5 \text { and } 1 \text { percent, respectively. P-values for differences in coefficients are from one-sided tests } \\
\text { using Stata's suest command. }\end{array}$} \\
\hline
\end{tabular}

ness to 19 percent. Controlling for competitiveness significantly reduces the gay income disadvantage which shrinks by 39 percent (by 70 percent when risk and confidence are also added in column 5), and reduces the straight gender gap by 3 percent (5 percent when combined with confidence and risk attitudes). As expected, competitiveness can not explain the income advantage of lesbians relative to straight women. Once we control for education in columns 9 and 10, the competitiveness coefficient becomes insignificant and the impact of competitiveness on the gender and gay effects is substantially reduced. This suggests that competitiveness affects income via an effect on education.

Table 5 presents results from ordered probit regressions of education level 
on sexual preference dummies. The regressions show that gays are on average higher educated than straight men and lesbians are higher educated than straight women. In column 4 , we add a competitiveness dummy to the regression. Competitiveness significantly and positively predicts the education level. Controlling for competitiveness significantly increases the gay education advantage and explains part of the education disadvantage of straight women vis-a-vis straight men but does not significantly affect the lesbian education advantage relative to straight women.

\section{Conclusions}

In this study we have proposed a new explanation of the systematic relationship between sexual orientation and earnings, namely taste for competition. If gays shy away from competition and lesbians compete too much, we argue that such sexual orientation differences in competitiveness could lead to a labour market in which there is a gay wage penalty for men and a lesbian wage premium for women. The evidence from our online experiment on competitiveness, which we link to information about subjects' sexual orientation and earnings, suggests that gays are indeed less competitive than straight men but lesbians are as competitive as straight women. This means that competitiveness cannot be the main mechanism that explains the link between sexual orientation and earnings.

The evidence on the gender gap in competitiveness as it is commonly observed in lab studies is quite clear. First, we show that the gender difference in competitive preferences found in student samples carries over to a representative sample of the Dutch population; that is, men are much more competitive than women. Second, we show that the measure of competitiveness which is most commonly used in the lab is a very strong predictor of earnings. And finally, we demonstrate that this simple experimental measure of competitiveness can account for a large and significant portion of gender differences in educational attainment and a smaller but significant portion of gender differences in earnings.

It is important, however, to keep in mind that competitiveness might be endogenous with respect to earnings rather than being a fixed trait. We mean here that working in competitive (and presumably well-paid) positions might increase people's willingness to compete. The same might be true of higher 
education. In analogy with the experimental literature on gender and competitiveness, our claim is therefore that individual preferences for competition have the potential to explain career differences between straight men and straight women, between straight men and gay men, but not between straight women and lesbian women.

\section{References}

Ahmed, Ali M, Lina Andersson, and Mats Hammarstedt. 2013. "Are gay men and lesbians discriminated against in the hiring process?" Southern Economic Journal 79 (3):565-585.

Akerlof, George A and Rachel E Kranton. 2000. "Economics and identity." Quarterly Journal of Economics 115 (3):715-753.

Antecol, Heather, Anneke Jong, and Michael Steinberger. 2008. "The sexual orientation wage gap: The role of occupational sorting and human capital." Industrial \& Labor Relations Review 61 (4):518-543.

Arrow, Kenneth J. 1973. "The Theory of Discrimination." In Discrimination in Labor Markets, edited by Orley Ashenfelter and eds Albert Rees. New Jersey: Princeton University Press.

Baumle, Amanda K and Dudley L Poston. 2011. "The economic cost of homosexuality: Multilevel analyses." Social Forces 89 (3):1005-1031.

Becker, Gary S. 1964. Human Capital Theory. Columbia, New York.

— 1971. The Economics of Discrimination. University of Chicago Press.

—. 1981. A Treatise on the Family. Harvard University Press.

Berge, Lars Ivar Oppedal, Kjetil Bjorvatn, Armando Jose Garcia Pires, and Bertil Tungodden. forthcoming. "Competitive in the lab, successful in the field?" Journal of Economic Behavior \& Organization .

Bertrand, Marianne. 2011. "New Perspectives on Gender." In Handbook of Labor Economics, vol. 4B, edited by Orley Ashenfelter and David Card. Elsevier, 1543 - 1590 . 
Black, Dan, Gary Gates, Seth Sanders, and Lowell Taylor. 2002. "Why do gay men live in San Francisco?" Journal of Urban Economics 51 (1):54-76.

Black, Dan A, Hoda R Makar, Seth G Sanders, and Lowell J Taylor. 2003. "The earnings effects of sexual orientation." Industrial \& Labor Relations Review 56 (3):449-469.

Black, Dan A, Seth G Sanders, and Lowell J Taylor. 2007. "The economics of lesbian and gay families." The Journal of Economic Perspectives 21 (2):5370.

Bosch, Nicole and Bas Van der Klaauw. 2012. "Analyzing female labor supplyEvidence from a Dutch tax reform." Labour Economics 19 (3):271-280.

Buser, Thomas, Muriel Niederle, and Hessel Oosterbeek. 2014. "Gender, competitiveness and career choices." Quarterly Journal of Economics 129 (3):1409-1447.

Dohmen, Thomas, Armin Falk, David Huffman, Uwe Sunde, Jurgen Schupp, and Gert G. Wagner. 2011. "Individual risk attitudes: Measurement, determinants, and behavioral consequences." Journal of the European Economic Association 9 (3):522-550.

Drydakis, Nick. 2009. "Sexual orientation discrimination in the labour market." Labour Economics 16 (4):364-372.

- 2011. "Women's sexual orientation and labor market outcomes in Greece." Feminist Economics 17 (1):89-117.

Flory, Jeffrey A, Uri Gneezy, Kenneth Leonard, and John A List. 2012. "Sex, competitiveness, and investment in offspring: On the origin of preferences." Working paper .

Flory, Jeffrey A., Andreas Leibbrandt, and John A. List. forthcoming. "Do competitive workplaces deter female workers? A large-scale natural field experiment on job-entry decisions." Review of Economic Studies .

Hammarstedt, Mats, Ali M Ahmed, and Lina Andersson. 2015. "Sexual prejudice and labor market outcomes for gays and lesbians: Evidence from Sweden." Feminist Economics 21 (1):90-109. 
Herek, Gregory M. 2000. "Sexual prejudice and gender: Do heterosexuals' attitudes toward lesbians and gay men differ?" Journal of Social Issues $56(2): 251-266$.

Kite, Mary E and Bernard E Whitley. 1996. "Sex differences in attitudes toward homosexual persons, behaviors, and civil Rights a meta-analysis." Personality and Social Psychology Bulletin 22 (4):336-353.

Klawitter, Marieka. 2015. "Meta-analysis of the effects of sexual orientation on earnings." Industrial Relations: A Journal of Economy and Society 54 (1):432 .

Mincer, Jacob. 1974. Schooling, Experience, and Earnings. New York: National Bureau of Economic Research.

Niederle, Muriel and Lise Vesterlund. 2007. "Do women shy away from competition? Do men compete too much?" The Quarterly Journal of Economics 122 (3):1067-1101.

__ 2011. "Gender and competition." Annual Review of Economics $3(1): 601-630$.

Phelps, Edmund S. 1972. "The statistical theory of racism and sexism." The American Economic Review 62 (4):659-661.

Plug, Erik, Dinand Webbink, and Nick Martin. 2014. "Sexual orientation, prejudice, and segregation." Journal of Labor Economics 32 (1):123-159.

Reuben, Ernesto, Matthew Wiswall, and Basit Zafar. 2013. "Preferences and biases in educational choices and labor market expectations: shrinking the black box of gender." Staff Report, Federal Reserve Bank of New York.

Tebaldi, Edinaldo and Bruce Elmslie. 2006. "Sexual orientation and labour supply." Applied Economics 38 (5):549-562.

Tilcsik, András. 2011. "Pride and prejudice: Employment discrimination against openly gay men in the United States." American Journal of Sociology 117 (2):586-626.

Weichselbaumer, Doris. 2003. "Sexual orientation discrimination in hiring." Labour Economics 10 (6):629-642. 
— 2015. "Testing for discrimination against lesbians of different marital status: A field experiment." Industrial Relations: A Journal of Economy and Society 54 (1):131-161.

Zhang, Y. Jane. 2012. "Can experimental economics explain competitive behavior outside the lab?" Working paper . 